\title{
DETERMINATION SOME OF HEAVY METALS IN TRADITIONAL FOOD IN NORTH AFRICA LIBYA AND EGYPT
}

EL-Tellawy, F. M. ${ }^{(1)}$; EL-Nawawy, M. A. ${ }^{(2)}$; Mahmoud, K. W. ${ }^{(3)}$; El- Zorkani, A. A. ${ }^{(4)}$ and Abd-Allah, Widad, M. E. ${ }^{(5)}$

1) Environmental Agricultural Dept,Environmental Studies and Research Institute, Ain Shams University 2) Food Science Dept, Faculty of Agriculture, Ain Shams University 3) Plant Protection Dept, Faculty of Agriculture, Ain Shams University 4) Microbiology and Immunology Dept, Facultyof Medicine, Tripoli University 5) Food Technology Dept, Faculty of Engineering and Technology, SabhaUniversity

\begin{abstract}
Thirty samples of ready traditional food were used in the present study, collected randomely from five different local markets (Faba bean, Falafel and Koshari), Abbasiya area, Nasr city, Ramses area, Ghamra area and Heliopolis at Cairo governorate . Also, five different traditional foods (Mbcabach, Couscous and Bazin) from local markets, In industrial area, Alhoreeh area, Almokhtar area, Albelad area, and Tobruk center at Tobruk city.The content of heavy metals, $\mathrm{Pb}, \mathrm{Cd}$ and $\mathrm{Al}$ in traditional food samples were determined using atomic absorption spectrometry (AAS).The results showed a significant variation in the concentration of these metals in Faba beans, Falafel and Kosharicollected from different market at Cairogov. The highest $\mathrm{Pb}$ level in Faba beans $(0.74 \mathrm{mg} / \mathrm{Kg})$ was found in Ramses sample. Aluminium (Al) content was recorded a high significant concentration in all traditional food samples and the highest concentration of $\mathrm{Al}$ was detected in Falafel (2.1 $\mathrm{mg} / \mathrm{kg}$ ) collected from Ghamra area. The results showed that the heavy metalcontents in Mbcabach, Couscous and Bazinthat collected from Tobruk city.The highest $\mathrm{Pb}$ and $\mathrm{Al}$ levels in two Bazin samples (0.61 and $1.09 \mathrm{mg} / \mathrm{kg}$ ) were in samples from Almokhtar and Alhoreeh sites. All samples of traditional food (Faba bean, Falafel and Koshari) collected from Egyptainlocal markets and (Mbcabach, Couscous and Bazin) collected from Libyan local markets were free of cadmiumcontamination.
\end{abstract}


Keywords: Heavy Metals, Contamination, Couscous, Koshari, Aluminium (Al).

\section{INTRODUCTION}

Food safety is a major public concern worldwide. During the last decades, the increasing demand for food safety has stimulated research regarding the risk associated with consumption of foodstuffs contaminated by pesticides, heavy metals and/or toxins (D’Mello, 2003).Aluminum is present in drinking water at usual levels of less than $0.2 \mathrm{mg} / \mathrm{L}$, and is also present in most foods naturally (normally at levels of less than $5 \mathrm{mg} / \mathrm{kg}$ ) or due to the use of aluminum cooking utensils and foil (Saiyed and Yokel., 2005).

Nasreddine et al (2006) had evaluated the dietary exposure of an adult urban population to three heavy metals (lead, cadmium and mercury) and to radionuclides. Exposure assessment was performed by means of the total diet study approach as recommended by the Word Health Organization (WHO). Five 'total diets' were collected during 2003-04. Average and maximal consumer exposure estimates to heavy metals were calculated and compared with appropriate reference values and with intakes reported from other countries. The average dietary intakes of lead, cadmium and mercury represented 7, 17and 5.6\%, respectively, of the appropriate provisional tolerable weekly intakes (PTWI). The mean dietary intake of methyl mercury represented $17.5 \%$ of the appropriate PTWI. Cs-134 and I-131 were not detected in any of the food samples. Traces of Cs-137 were only found in five food samples. 
Lead is toxic heavy metal, Water and food are the most important sources of human exposure to lead, a product from the combustion of fuel and industrial waste emitted into the air and then deposition in soil and surface water then to plants and agricultural crops. Stipulates (LNCSM: 594/ 2009) that the level of lead in food produced from cereals and legumes should not exceed to $0.2 \mathrm{mg} / \mathrm{kg}$.

Analyzed by Perkin Elmer Plasma 400 emission spectrometer for the determination of lead, cadmium, copper, zinc and aluminum in ready to eat chicken shawarma (Mohamed and Nosier, 2009). The obtained results showed that the average value of $\mathrm{Pb}, \mathrm{Cd}, \mathrm{Cu}, \mathrm{Zn}$ and $\mathrm{Al}$ were 1.484-1.771, $0.338-0.435,2.854-2.642,24.422-11.032$ and $155.113-68.777 \mathrm{ppm}$ respectively. High levels of aluminum and lead were determined in samples as contamination and preparation methods of shawarma played animportant role in the presence of high levels of heavy metals which considered to be a risky health hazard.

Heavy metals may be present in agricultural soils at low levels but can be accumulated by plant over a period. So, researchers all over the world to study the pollution with heavy metals of air, water, and foods to avoid their harmful effects and to determine their suitability for human consumption (Naeem et al., 2009.; Nkansah and Sarojam and Chen, 2010).

In the roasted plantain in the low income area had the highest level of contaminants such as $\mathrm{Pb}, \mathrm{Cd}, \mathrm{Zn}$ and $\mathrm{Fe}$. The lowest value was in the high income area (Opeolu et al., 2010) . Lead levels ranged between 0.2-1.25 $\mu \mathrm{g} / \mathrm{g}$ with the highest value observed at the low income, high population density and high traffic area. $\mathrm{Cd}, \mathrm{Zc}$ and Fe levels also followed a similar trend in the 
other three States. They ranged between $0.48-18.3 \mu \mathrm{g} / \mathrm{g}, 2.0-4.5 \mu \mathrm{g} / \mathrm{g}$ and 0.4 $13.5 \mu \mathrm{g} / \mathrm{g}$ respectively. It is opined that the pollution sources for the roasted plantain and maize include those from emissions from leaded gasoline.

Lead contamination has been analyzed in 104 of the representative food items in the Saudi diet and to estimate the dietary lead intake of Saudi Arabians. Three samples of each selected food items were purchased from the local markets of Riyadh city, the capital of Saudi Arabia. Each pooled sample was analyzed in triplicate by ICP-AES after thorough homogenization. Sweets $(0.011-0.199 \mu \mathrm{g} / \mathrm{g})$, vegetables $(0.002-0.195 \mu \mathrm{g} / \mathrm{g})$, legumes $(0.014$ $0.094 \mu \mathrm{g} / \mathrm{g})$, eggs $(0.079 \mu \mathrm{g} / \mathrm{g})$, meat and meat products $(0.013-0.068 \mu \mathrm{g} / \mathrm{g})$ were the richest sources of lead. Considering the amounts of each food consumed, the major food sources of lead intake for Saudi can be arranged as follows: vegetables $(25.4 \%)$, cereal and cereal products $(24.2 \%)$, beverages $(9.7 \%)$ sweets $(8.2 \%)$, legumes $(7.4 \%)$, fruits $(5.4 \%)$ milk and milk products $(5.1 \%)$.The results showed that the daily intakes of lead according to the two sources are 22.7 and $24.5 \mu \mathrm{g} /$ person/day respectively (Al- Othman,2010).

The joint FAO/WHO, 2011 Expert Committee on Food Additives (JECFA, 2011) established the Provisional to Terable Weekly Intake (PTWI) for $\mathrm{Al}$ of $7.0 \mathrm{mg}$ per $\mathrm{kg}$ bodyweight in 1989. The JECFA re-evaluated the safety of of aluminum and lowered the PTWI to $1.0 \mathrm{mg}$ per $\mathrm{kg}$ body weight because of the potential for $\mathrm{Al}$ to affect there productive and nervous system in experimental animals in 2007. However, the JECFA revised the PTWI to $2.0 \mathrm{mg}$ per $\mathrm{kg}$ body weight in 2011 (Joint FAO/WHO ECFA, 2011) as a result of new bioavailability and toxicological data (Poirier et al., 2011). 
Heavy metals toxicity can affect mental development and central nervous system functions alter the blood compositic and disturb the function of organs like kidneys lungs and liver (Filon et al., 2013.;Hajeb and Sloth, 2014). Cadmium $(\mathrm{Cd})$ is one of the most toxic elements in world and human exposure can result in the development of various diseases, $\mathrm{Cd}$ can accumulate in the body with a half-life 10 to 30 years. Lead $(\mathrm{Pb})$ and $\mathrm{Cd}$ are highly toxic elements, which quickly absorbed from the alimentary trace. Afterwards, they easily pass through biological barriers and accumulation in internal organs. Even small amounts of $\mathrm{Pb}$ and $\mathrm{Cd}$ may cause metabolic disorders.Food contamination is generally defined as foods that are spoiled or tainted because they either contain microorganisms, such as bacteria or parasites, or toxic substances that make them unfit for consumption. A food contaminant can be biological, chemical or physical in nature, with the former being more common.Chemical food contaminants that can enter the food supply chain include pesticides, heavy metals, and other alien chemical agents(Malik, 2016).

\section{MATERIALS AND METHODS}

Materials: Thirty samples of ready traditional foodFaba beans, Falafel and Koshari were used in the present study, collected by a simple random sampling method from five different local marketsat Cairo governorate in Egypt and five different local markets Coucous, Mbcabach and Bazin from Tobruk city in Libya. Five Kilograms cooked traditional food samples were collected from every local markets "Egypt and Libya" in sterile plastic bags in Ice-Boxduring transportation to the laboratory, according to (Cheesbrough, 1984), for a period of two month in autumn (2016). 
- Falafel: fried patties from minced mixture of dehulled faba bean, onion, leek, herpes and spices.

- Faba beans: included of cooked whole Faba beans and salt.

- Koshari: formed of cooked rice, macaroni, whole lentil, tomato sauce and fried onion.

- Couscous: composed of milled wheat cooked on the steam with lamb meat broth, onion, tomato, chick pean,salt and spices (Diari made in Tunisia).

- Mbcabach: included of cooked pasta with meat, onion, tomato, salt and spices (Spaga made in Tunisia) .

- Bazin: composed of barley flour cooked in water and salt (Local producer).

- All samples were cooked at $100^{\circ} \mathrm{C}$ except Falafel was fried at $175-180^{\circ} \mathrm{C}$.

Methods: About $1 \mathrm{~g}$ of accurately weighed dry samples (at $70^{\circ} \mathrm{C}$ overnight) of the collected samples were boiled in $50 \mathrm{~mL}$ of deionized tridistilled water acidified with $1 \mathrm{~mL}$ concentrated nitric acid, (Juranovic et al., 2013). The samples evaporated till reach less than $25 \mathrm{~mL}$. The infusions were cooled and accurately poured into $50 \mathrm{~mL}$ volumetric flasks and completed to the mark with deionized water. Single sample of each sample was digested in nitric acid + hydrogen peroxide mixture and diluted with deionized water to $50 \mathrm{~mL}$ for comparison measurements.Determination of heavy metals in traditional food samples were performed according to the method of (AOAC, 1995).

All chemicals and standards are of Analytical grade. Metals stock standards of, $\mathrm{Pb}, \mathrm{Cd}$ and $\mathrm{Al}$ were obtained from Merck, Darmstadt, Germany (1000 mg/L). 
The recovery and reproducibility of the method was tested continuously by clean samples with each of the metals at concentration levels ranged between 0.03 and $0.05 \mathrm{mg} / \mathrm{kg}$ and treated. The performance of the AAS was frequently tested by measuring the characteristic mass. The average recoveries for digested samples ranged between $88 \%$ and $95 \%$. The average recoveries for infusions ranged between $50 \%$ and $65 \%$. Blank Samples were analyzed with every set of samples and the detection limits (i.e., the concentration produces an absorbance signal three times the magnitude of the baseline noise $3 \sigma$ (Beaty and Kerber, 1993) were estimated for each measured metal.

\section{STATISTICAL ANALYSIS}

Data analysis by two modeles, one way analysis of variance $\mathrm{Yij}=\mathrm{M}+$ Loci+ eij, and two way analysis with interaction by (SAS, 2006) program at $(\mathrm{P}<0.05)$, Yijk= M+ loci+ Pestiij+ $($ Loc* Pesti $) i j+$ eijk.

\section{RESULTSANDDISCUSSION}

Detection of heavy metals in traditional food samples collected from local markets at Cairo and Tobruk cities

Detection of heavy metals in 15 food samples cooked (Faba beans, Falafel and koshari) samples collected from some local Egyptian markets (Abbasiya area, Nasr city, Ramsis area, Ghamra area and Heliopolois ) in Cairo governorate.

Data inTables (1) and Fig (1 to 3) demonstrated the average concentrations of metals in 15 samples of traditional food (Faba beans, Falafel and Koshari). Some samples were contaminated with different 
amounts of heavy metals. Each of those was contaminated with one or more of heavy metals.

Table (1): Detection of metals (mg/kg of dry weight) in 15 traditional food(Faba beans, Falafel and Koshari) samples collected from Egypt .

\begin{tabular}{|c|c|c|c|c|c|c|}
\hline \multirow[b]{2}{*}{$\begin{array}{l}\text { Heavy } \\
\text { metals }\end{array}$} & \multicolumn{6}{|c|}{ Samples location } \\
\hline & $\begin{array}{l}\text { Traditional } \\
\text { food }\end{array}$ & $\begin{array}{c}\text { Abbasiya } \\
\text { area } \\
(\mathrm{mg} / \mathrm{kg})\end{array}$ & $\begin{array}{c}\text { Nasr } \\
\text { city } \\
(\mathbf{m g} / \mathbf{k g})\end{array}$ & $\begin{array}{c}\text { Ramses } \\
\text { area } \\
(\mathrm{mg} / \mathrm{kg})\end{array}$ & $\begin{array}{c}\text { Ghamra } \\
\text { area } \\
\text { (mg/kg) }\end{array}$ & $\begin{array}{c}\text { Heliopolois } \\
\text { (mg/kg) }\end{array}$ \\
\hline $\mathrm{Pb}$ & \multirow{3}{*}{ Faba beans } & N.D ${ }^{d}$ & $0.34^{\mathbf{b}}$ & $0.74^{\mathrm{a}}$ & $0.33^{\mathbf{b}}$ & $0.21^{\mathrm{c}}$ \\
\hline $\mathrm{Cd}$ & & N.D & N.D & N.D & N.D & N.D \\
\hline $\mathrm{Al}$ & & $1.48^{\mathrm{a}}$ & $0.47^{\mathrm{c}}$ & $1.81^{\mathrm{b}}$ & $1.32^{\mathrm{a}}$ & $0.73^{\mathbf{b}}$ \\
\hline $\mathrm{Pb}$ & \multirow{3}{*}{ Flafel } & N.D ${ }^{c}$ & N.D ${ }^{c}$ & $0.45^{\mathrm{b}}$ & $0.60^{\mathrm{a}}$ & N.D ${ }^{c}$ \\
\hline $\mathrm{Cd}$ & & N.D & N.D & N.D & N.D & N.D \\
\hline $\mathrm{Al}$ & & $2.08^{\mathrm{a}}$ & $1.73^{b}$ & $2.04^{\mathrm{a}}$ & $2.1^{\mathrm{d}}$ & $1.08^{\mathrm{c}}$ \\
\hline $\mathrm{Pb}$ & \multirow{3}{*}{ Koshari } & $0.28^{\mathbf{a b}}$ & N.D ${ }^{b}$ & $0.51^{\mathrm{a}}$ & $0.33^{\mathrm{a}}$ & $0.23^{\mathbf{a b}}$ \\
\hline $\mathrm{Cd}$ & & N.D & N.D & N.D & N.D & N.D \\
\hline $\mathrm{Al}$ & & $0.45^{\mathrm{a}}$ & $0.38^{\mathrm{a}}$ & $0.63^{a}$ & $0.46^{\mathrm{a}}$ & $0.44^{\mathrm{a}}$ \\
\hline
\end{tabular}

N.D $=$ No detected

The mean values for the content of $\mathrm{Pb}, \mathrm{Cd}$ and $\mathrm{Al}$ in traditional foodFaba beans, Falafel and Koshari (expressed in $\mathrm{mg} / \mathrm{kg}$ of dry weight) represented in Tables (1 and 2) and Fig (1 to 3), respectively. The results showed that, ten samples of traditional food Faba beans, Falafel and Koshari were contaminated with lead. One sample (Faba bean) was free of lead which collected from Abbasiya area, while 4 samples of Faba beansNasr city, Ramses area, Ghamra area, and Heliopolis were recorded0.34, 0.74, 0.33 and $0.21 \mathrm{mg} / \mathrm{kg}$ of lead, respectively.The highest value in Faba beans collected from Ramses area and there were significant differences at $(\mathrm{P}<0.05)$ among the different food samples. Three samples of Falafel in the same Table and Fig(2) collected from Abbasiya area, Nasr city and Heliopolis were free from 
lead, while, two samples of Falafel from Ramses area and Ghamra area, recorded (0.45 and $0.6 \mathrm{mg} / \mathrm{kg})$,respectively. However, four samples of KoshariAbbasiya area, Ramses area, Ghamra area, and Heliopolis were detectable $0.28,0.51$ and $0.23 \mathrm{mg} / \mathrm{kgof}$ lead, respectively in same Tables and Figure (3).
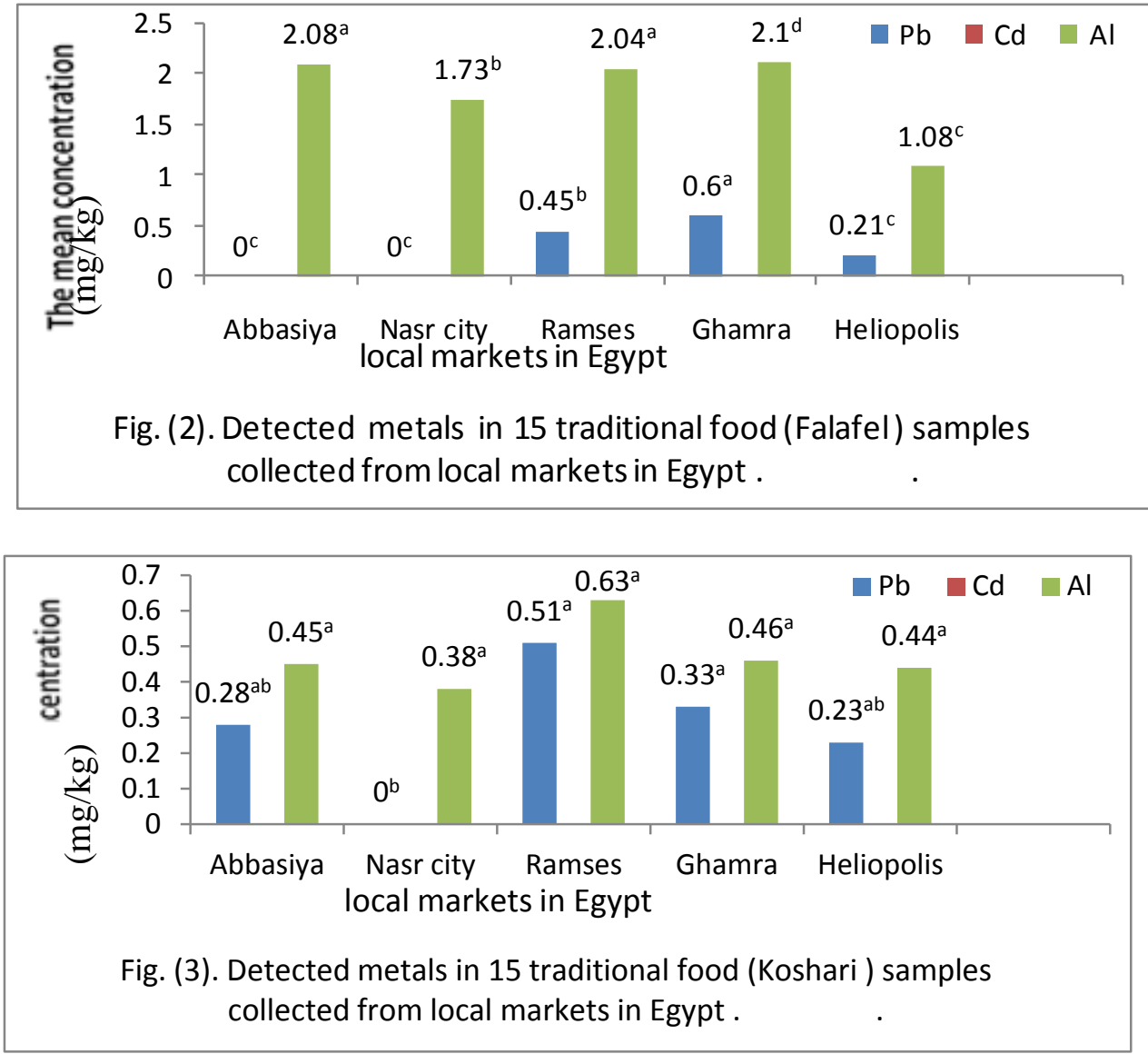

The mean values of Al in Faba beans, Falafel and Kosharirepresented in the same Table and Figure (1) of Aluminium. All samplesof Faba bean 1.48, $0.47,1.81,1.32$ and $0.73 \mathrm{mg} / \mathrm{kg}$ from Abbasiya, Nasr city, Ramses, Ghamra 
and Heliopolis, respectively. Two samples were lower than the standard limitMPL of Faba beans from Nasr city and Heliopolis, and there were significant differences between food samples. Whereas, the highest $\mathrm{Al}$ contents were observed in fried Falafel 2.08, 1.73, 2.04, 2.1 and 1.08 mg/kgfrom Abbasiya, Nasr city, Ramses, Ghamra and Heliopolis, respectively.There were significant differences between them and all samples of Falafel were exceeding the MPL of AL $1 \mathrm{mg} / \mathrm{kg}$. The results clearly indicate that the use of aluminum utensils for cooking contributes significantly to the daily intake of aluminum through the cooked foods. According to the World Health Organization (WHO), the obtained values considered to be unacceptable. Data in the same Table and Figure (3), illustrates that there were a low level of Al element in Koshari samples.Lower than the maximum level $(1 \mathrm{mg} / \mathrm{kg})$ and no significant differences $(\mathrm{P}<0.05)$, were contained $0.45,0.38,0.63,0.46$ and $0.44 \mathrm{mg} / \mathrm{kg}$, respectively. The levels of metals in all samples were lower than the (Abd El-Rahman et al ., 2015). 
Table(2): Minimum, maximum, mean, standard deviation, contamination, maximum permissible limits (MPLs ) and violation of heavy metals monitored in15 traditional food (Faba beans, Falafel and Koshari) samples collected from Egypt.

\begin{tabular}{|c|c|c|c|c|c|c|c|}
\hline \multirow[t]{2}{*}{$\begin{array}{l}\text { Heavy } \\
\text { metals }\end{array}$} & \multirow[t]{2}{*}{$\begin{array}{l}\text { Traditioal } \\
\text { food }\end{array}$} & \multirow[t]{2}{*}{$\begin{array}{c}\text { Range: } \\
(\text { Min-Max }) \\
(\text { mean } \pm \text { SD) } \\
(\mathrm{mg} / \mathrm{kg}) \\
* \mathrm{~N}=5\end{array}$} & \multicolumn{2}{|c|}{$\begin{array}{l}\text { Contaminated } \\
\text { Samples }\end{array}$} & \multirow[t]{2}{*}{$\begin{array}{c}\text { MPLs } \\
(\mathbf{m g} / \mathbf{k g})\end{array}$} & \multicolumn{2}{|c|}{$\begin{array}{c}\text { Violated } \\
\text { Samples } \\
\text { after } \\
\text { purification }\end{array}$} \\
\hline & & & No. & $\%$. & & No. & $\%$. \\
\hline $\mathrm{Pb}$ & \multirow{3}{*}{ Faba beans } & $\begin{array}{c}(0.21-0.74) \\
(0.405 \pm 0.01)\end{array}$ & 4 & 80 & 0.2 & 3 & 60 \\
\hline $\mathrm{Cd}$ & & 0 & 0 & 0 & 0.1 & 0 & 0 \\
\hline $\mathrm{Al}$ & & $( \pm 0.04)$ & 5 & 100 & 1 & 2 & 40 \\
\hline $\mathrm{Pb}$ & \multirow{3}{*}{ Falafel } & $\begin{array}{c}\text { (nd-0.6) } \\
(0.525 \pm 0.02)\end{array}$ & 2 & 40 & 0.2 & 2 & 40 \\
\hline $\mathrm{Cd}$ & & 0 & 0 & 0 & 0.1 & 0 & 0 \\
\hline $\mathrm{Al}$ & & $\begin{array}{l}(0.0180-0.21) \\
(0.0903 \pm 0.03)\end{array}$ & 5 & 100 & 1 & 2 & 40 \\
\hline $\mathrm{Pb}$ & \multirow{3}{*}{ Koshari } & $\begin{array}{c}(0.23-0.51) \\
(0.3375 \pm 0.02)\end{array}$ & 4 & 80 & 0.2 & 2 & 40 \\
\hline $\mathrm{Cd}$ & & 0 & 0 & 0 & 0.1 & 0 & 0 \\
\hline $\mathrm{Al}$ & & $\begin{array}{c}(0.038-0.63) \\
(0.1606 \pm 0.02)\end{array}$ & 5 & 100 & 1 & 1 & 20 \\
\hline
\end{tabular}

Recommended Max.limit for European Union 2006 Commission Regulation (EC) No 1881/2006 andJoint FAO/WHO, 2011

The average concentrations of Aluminum in Faba beans, Falafel and Koshari were $0.04,0.903$ and $0.1606 \mathrm{mg} / \mathrm{kg}$ Table (2), respectively.Falafel and Koshari recoded 100\% while Faba bean samples were recorded $80 \%$.The high contamination levels found in some vegetables may be related to pollutants in irrigation water, farm soil or pollution from highway traffic.Al content was found to be lower than the standard limit for (EC, 2006) in all samples. 
All samples of traditional food Faba beans, Falafel and Koshari were free from any detectable of cadmium.

Detection of heavy metals 15 samples of local Libyan traditional food (Mbcabach, Couscous and Bazin)from local markets in Tobruk city

Fifteen samples of traditional food Mbcabach, Couscous and Bazin were collected from local markets in Industrial area, Alhoreeh area, Almokhtar area, Albelad area, and Tobruk center at Libya, to detect the contamination of some heavy metals. The mean values of $\mathrm{Pb}, \mathrm{Cd}$ and $\mathrm{Al}$ in Libyan traditional food (expressed in $\mathrm{mg} / \mathrm{kg}$ of dry weight) were represented in Tables $(3,4)$ and, Fig $(4,5$ and 6$)$.

Table (3): Detection of metals (mg/kg of dry weight) in 15 traditional food (Mbcabach, Couscous and Bazin) samples collected from libya .

\begin{tabular}{|c|c|c|c|c|c|c|}
\hline \multirow{2}{*}{$\begin{array}{l}\text { Heavy } \\
\text { metals } \\
\text { mg/kg }\end{array}$} & \multicolumn{6}{|c|}{ "Samples location } \\
\hline & $\begin{array}{l}\text { Traditional } \\
\text { food }\end{array}$ & Industrial & Alhoreeh & Almokhtar & Albelad & $\begin{array}{l}\text { Tobruk } \\
\text { center }\end{array}$ \\
\hline $\mathrm{Pb}$ & \multirow{3}{*}{ Mbcabach } & $0.06 \mathrm{a}$ & N.D b & $0.08 \mathrm{a}$ & $0.07 \mathrm{a}$ & $0.04 \mathrm{ab}$ \\
\hline $\mathrm{Cd}$ & & N.D & N.D & N.D & N.D & N.D \\
\hline $\mathrm{Al}$ & & $0.27 \mathrm{a}$ & $0.29 a$ & $0.31 \mathrm{a}$ & $0.32 \mathrm{a}$ & $0.26 a$ \\
\hline $\mathrm{Pb}$ & \multirow{3}{*}{ Couscous } & $0.04 a b$ & N.D c & $0.05 a$ & $0.03 \mathrm{ab}$ & $0.03 a$ \\
\hline$\overline{\mathrm{Cd}}$ & & N.D & N.D & N.D & N.D & N.D \\
\hline $\mathrm{Al}$ & & $0.46 \mathrm{a}$ & $0.55 a$ & $0.43 \mathrm{a}$ & $0.42 \mathrm{a}$ & $0.39 \mathrm{a}$ \\
\hline $\mathrm{Pb}$ & \multirow{3}{*}{ Bazin } & $0.42 \mathrm{ab}$ & $0.31 \mathrm{~b}$ & $0.61 \mathrm{a}$ & $0.53 \mathrm{a}$ & $0.41 \mathrm{ab}$ \\
\hline $\mathrm{Cd}$ & & N.D & N.D & N.D & N.D & N.D \\
\hline $\mathrm{Al}$ & & $0.79 \mathrm{~b}$ & $1.09 \mathrm{a}$ & $0.81 \mathrm{~b}$ & $0.85 b$ & $0.87 \mathrm{ab}$ \\
\hline
\end{tabular}

N.D $=$ No Detected

Data in Table (3) and Fig (4) showed concentration of lead $(\mathrm{Pb})$ in samples of traditional food Mbcabach, Couscous and Bazin. One sample Mbcabach was free of lead which collected from Alhoreeharea, while, 4 
samples of Mbcabach that collcted from Industrial area, Almoktar area, Albelad area and Tobruk center were recorded 0.06, 0.08, 0.07 and 0.04 $\mathrm{mg} / \mathrm{kg}$,respectively. These results were least than the LNCSM: 3/ 2008 and showed no significant differences $(\mathrm{P}<0.05)$. One samples of Couscous was free of lead which collected from Alhoreeh area, while, 4 samples of Couscousfrom Industrial area, Almoktar area, Albelad area and Tobruk center recorded $0.04,0.05,0.03$ and $0.03 \mathrm{mg} / \mathrm{kgof}$ lead, respectively in the same Table and Figure (5). These results were least than the (LNCSM: 609/ 2009 andJoanna et al., 2013) and showed no significant differences at $(\mathrm{P}<0.05)$. Five samples of Bazin in the same Table and Figure (6) illustrates that there were a high level of $\mathrm{Pb}$ element in Bazin samples than the maximum level $(0.2 \mathrm{mg} / \mathrm{kg})$ and showed significant differences were detectable of lead 0.42 , 0.31, 0.61, 0.53 and $0.41 \mathrm{mg} / \mathrm{kgfrom}$ Industrial area, Alhoreeh area, Almoktar area, Albelad area and Tobruk center, respectively. These results were the highest than the (LNCSM: 594/ 2009).

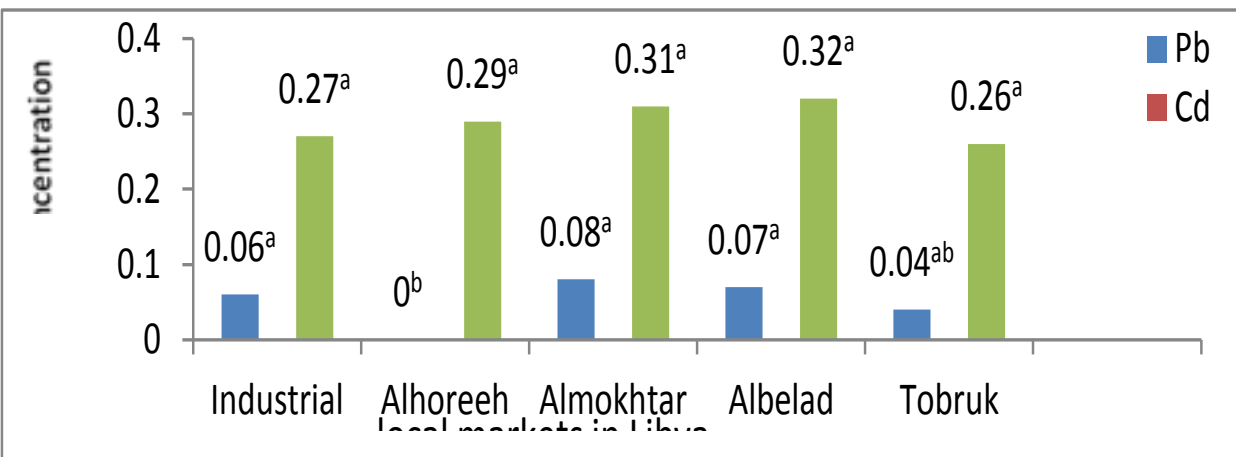

Fig. (4). Detected metals in 15 traditional food (Mbcabach) samples 
J. Environ. Sci.

Institute of Environmental Studies and Research - Ain Shams University
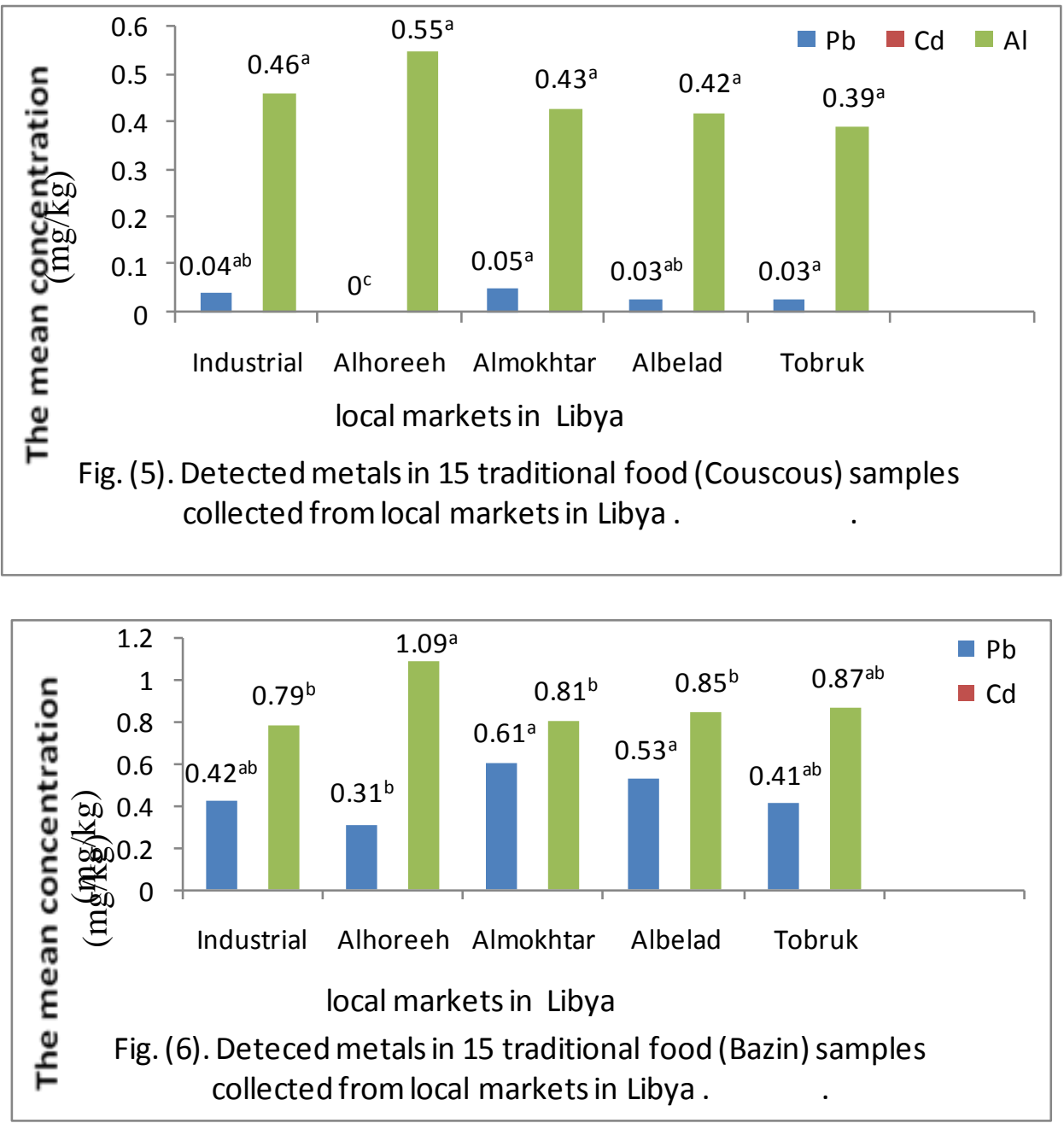

The average concentrations of lead in 13 samples of traditional food Mbcabach, Couscous and Bazin were 0.0625, 0.0375and $0.452 \mathrm{mg} / \mathrm{kg}$, respectively in Table (4). Lead contamination of food arises as a result of environmental emissions, such as mining and the now diminished use of leaded petrol. Eight samples of traditional food Mbcabach and Couscous were 
lower than the MPL of lead $(0.2 \mathrm{mg} / \mathrm{kg})$.While,Bazin samples were recorded the highest $100 \%$ of lead andexceeding the the MPL.

Table(4): Minimum, maximum, mean, standard deviation, contamination, maximum permissible limits (MPLs ) and violation of heavy metals monitored in 15 traditional food (Mbcabach, Couscous and Bazin) samples collected from Libya.

\begin{tabular}{|c|c|c|c|c|c|c|c|}
\hline \multirow[t]{2}{*}{$\begin{array}{l}\text { Heavy } \\
\text { metals } \\
\text { mg/kg }\end{array}$} & \multirow[t]{2}{*}{$\begin{array}{l}\text { Traditional } \\
\text { food }\end{array}$} & \multirow{2}{*}{$\begin{array}{c}\text { Range: } \\
(\text { Min-Max }) \\
(\text { mean } \pm \text { SD }) \\
(\mathrm{mg} / \mathbf{k g}) \\
* \mathrm{~N}=5\end{array}$} & \multicolumn{2}{|c|}{$\begin{array}{l}\text { Contaminated } \\
\text { Samples }\end{array}$} & \multirow[t]{2}{*}{$\begin{array}{l}\text { MPLs } \\
(\mathrm{mg} / \mathrm{kg})\end{array}$} & \multicolumn{2}{|c|}{$\begin{array}{c}\text { Violated } \\
\text { Samples } \\
\text { after } \\
\text { purification }\end{array}$} \\
\hline & & & No. & $\%$. & & No. & $\%$. \\
\hline $\mathrm{Pb}$ & \multirow{3}{*}{ Mbcabach } & $\begin{array}{c}(0.04-0.08) \\
(0.0625 \pm 0.01)\end{array}$ & 4 & 80 & 0.2 & 0 & 0 \\
\hline $\mathrm{Cd}$ & & 0 & 0 & 0 & 0.1 & 0 & 0 \\
\hline $\mathrm{Al}$ & & $\begin{array}{c}(0.027-0.32) \\
(0.101 \pm 0.02)\end{array}$ & 5 & 100 & 1 & 1 & 20 \\
\hline $\mathrm{Pb}$ & \multirow{3}{*}{ Couscous } & $\begin{array}{c}(0.03-0.05) \\
(0.0375 \pm 0.01)\end{array}$ & 4 & 80 & 0.2 & 0 & 0 \\
\hline $\mathrm{Cd}$ & & 0 & 0 & 0 & 0.1 & 0 & 0 \\
\hline $\mathrm{Al}$ & & $\begin{array}{l}(0.39-0.55) \\
(0.44 \pm 0.03)\end{array}$ & 5 & 100 & 1 & 5 & 100 \\
\hline $\mathrm{Pb}$ & \multirow{3}{*}{ Bazin } & $\begin{array}{c}(0.31-0.61) \\
(0.452 \pm 0.03)\end{array}$ & 5 & 100 & 0.2 & 5 & 100 \\
\hline $\mathrm{Cd}$ & & 0 & 0 & 0 & 0.1 & 0 & 0 \\
\hline $\mathrm{Al}$ & & $\begin{array}{l}(0.09-0.49) \\
(0.32 \pm 0.04)\end{array}$ & 5 & 100 & 1 & 4 & 80 \\
\hline
\end{tabular}

Recommended Max.limit for European Union 2006 Commission Regulation (EC) No 1881/2006 andJOINT FAO/WHO, 2011

Data in the same Tables $(3,4)$ andFig $(4,5$ and 6) demonstrated the average concentrations of metals in 15 samples of traditional food Mbcabach, Couscous and Bazin. All samples were found to be contaminated with different amounts of Al. Mbcabach sample in the Table (3) and Figure (4) 
were $0.27,0.29,0.31,0.32$ and $0.26 \mathrm{mg} / \mathrm{kgof}$ Aluminum which collected from Industrial area, Alhoreeharea, Almoktar area, Albelad area and Tobruk center, respectively. These results were least than the MPL $1 \mathrm{mg} / \mathrm{kg}$ and showed significant differences at $(\mathrm{P}<0.05)$. While the mean values for the content of $\mathrm{Al}$ in Couscous samples in the Table (3) and Figure (5) were 0.46, 0.55, 0.43, 0.42 and $0.39 \mathrm{mg} / \mathrm{kg}$ which collected from Industrial area, Alhoreeharea, Almoktar area, Albelad area and Tobruk center, respectively and these results were least than the MPL $1 \mathrm{mg} / \mathrm{kg}$ and no significant differences at $(\mathrm{P}<0.05)$. Five samples of Bazin in the same Table (3) and Figure (6) were recorded $0.79,1.09,0.81,0.85$ and $0.87 \mathrm{mg} / \mathrm{kgof}$ Alfrom Industrial area, Alhoreeh area, Almoktar area, Albelad area and Tobruk center, respectively. All samples were the lower than the MPL $1 \mathrm{mg} / \mathrm{kg}$ except one sample from Alhoreeh area and there were no significant differences at $(\mathrm{P}<0.05)$ between Bazin samples fromIndustrial area, Almoktar area andAlbelad area. The results indicate that the use of $\mathrm{Al}$ utensils for cooking contributes significantly to the daily intake of aluminum through the cooked foodsThese results were less than mentioned by Muhammad (Mohamed and Nosier, 2009).

The average concentrations of $\mathrm{Al}$ in 15 samples of traditional food Mbcabach, Couscous and Bazin were $0.101,0.44$ and $0.32 \mathrm{mg} / \mathrm{kg}$, respectively. All food samplesMbcabach, Couscous and Bazin were recorded with $\mathrm{Al} 80 \%, 80 \%$ and $100 \%$, respectively.

All samples of traditional food (Mbcabach, Couscous and Bazin) were free from any detectable of cadmium. 


\section{REFERENCES}

Abd El-RahmanHanaa, S. M.; Abeer, M. N. H. El-Dakak and Zein, H. (2015): Investigation and evaluation on heavy metal contaminations of green salads and potato fried in different restaurants and fresh vegetables in same Egyptian Governonate. Inter. Enviro. Monit.Analy. 3: 28-37.

Al-OthmanZeid, A. (2010): Lead contamination in selected foods from Riyadh city market and estimation of the daily intake.Moleculers. 15: 7482-7497.

AOAC, Association of Official Analytical Chemist (1995): Official methods of analysis. Pesticide and Industrial Chemical Residues, 16 th ed. A. O. A. C. Arlington, Virginia, USA.

Beaty, D. Richard and Kerber, D. Jack.(1993): Concepts, Instrumebtation and Techniques in Atomic Absorption Spectrophotometry.Sec, Ed. Perkin. Elmer, Corporation. USA.

Cheesbrough, M. (1984): Microbiological examination of specimens and biochemical testing of microorganisms in: Medical laboratory manual of tropical countries. 1sted.Vol 2.Tropical Health Technology. Great Britain at University Press, Cambridge pp. 2639, 57-69.

D’Mello, J. P. F. (2003): Food safety: Contaminants and toxins.Cambridge: CABI Publishing.

E C, Commission Regulation No 1881/ 2006. Setting maximum levels for certain contamination in foodstuffs.O. J. L. p, 32.

Filon, J., Ustymowicz-Farbiszewska, J., Gorsk, i. J. and Karczewski, J. (2013): Contamination of cereal products with lead and cadmium as a risk factor to health of the population in the province of podlasie. J. Elements Science 381-390.

Hajeb, P. and Sloth, J. J. (2014): Occurrence, binding and Reduction approaches com. Rev, Food sciences. Food safety ,13, 457-472. 
JuranovićCindrIva, Michaela Zeiner, Eva Glamuzina and Gerhard Stingeder. (2013): Elemental characterisation of the medical herbs Salvia officinalis L. and Teucrium montanum L. grown in Croatia, Microchemical J. 107: 185-189.

Joanna Filon.; Jolanta Ustymowicz-Farbiszewska.; Jan Gorski and Jan Karczewski.(2013): Contamination of cereal products with lead and cadmium as a factor of a health risk for people in Podlaskie Voivodship.J. Elem. 381-390.

Joint FAO/WHO Expert Committee on Food Additives.(2011): Evaluation of certain food additives and contaminants.WHO Tech. Rep. Ser. 966:7-17.

LNCSM 3: 2008. Macarroni.1st ed. Libyan National Center for Standardiztion and Metrology. Libya.

LNCSM: 594/ 2009. Maximum permissible level lead in food, animal feed and drinking water.Libyan National Center for Standardiztion and Metrology. Libya.

LNCSM: 609/ 2009. Couscous.Libyan National Center for Standardiztion and Metrology. Libya.

Malik Altaf Hussain. (2016): Food contamination: Major challenges of the future. doi: 10. 3390/foods 5020021.WWW.mdpi.com/ Journal/ Foods. New Zealand.

Mohamed, Sh. Hala and Nosier, M. Shireen.(2009): Estimation of some heavy metals in chicken shawarma.Egypt.J.Comp.Path and Clinic.Path. 22. 3:24-36.

Nasreddine.L; Hwalla.N; El Samad. O; Leblanc.J.C; Hamze.M; Sibiril.Y, and Parent-Massin, D. (2006): Dietary exposure to lead, cadmium, mercury and radionuclidesof an adult urban population in Lebanon: A total diet study approach. Food Additives Contaminants. 23(6):579-590.

Naeem, I.; Mubeen ,H.; Taskeen, A. and Saddiqe, Z. (2009): "Investigations of heavy metals in commercial spices brands". New York Science Journal,vol. 2. 20-26. 
Nkansah, M. and Amoako, C. (2010): "Heavy metal content of some common spices available in markets in the Kumasi metropolis of Ghana".American Jou.Scientific and Industrial Research, 1.158163.

Opeolu. B. O; Adebayo. K; Okuneye. P. A and Badru.F. A. (2010): Physicochemical and microbial assessment of Roadside food and water samples in Lagos and Environs. J. Scie. Environ. Manage. 14(1) 29-34.

Poirier, J., H. Semple, J. Davies, R. Lapointe, M. Dziwenka and M.Hiltz. (2011): Double-blind,vehicle-controlled randomized twelvemonth neuro developmental toxicitystudy of common aluminum salts in the rat. Neuroscience. 193:338-362.

Saiyed SM and Yokel RA (2005): Aluminium content of some foods and food products in the USA. Food Additives and Contaminants, 22(3): $234-44$.

Sarojam, P. and Chen, J. (2010): "Analysis of Arsenic , Cadmium and Lead in Chinese Spice Mixtures using Graphite Furnace Atomic Absorption Spectrophotometry". 1-6. USA.

SAS. (2006). Statisical Analysis System, SAS user's guid: Statisitcs. SAS Inc. Editors, Cary,NC. 


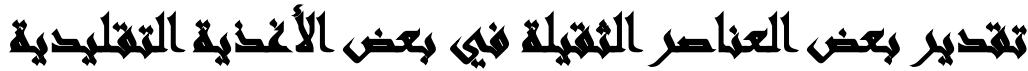

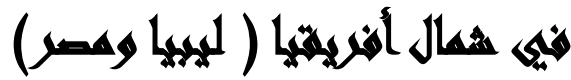

$[r]$

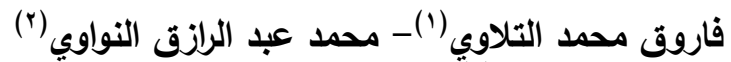

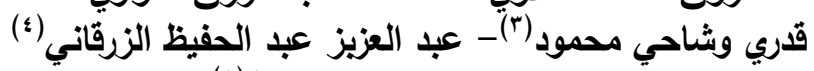 \\ وداد محمد الفيتوري عبدالله (ه)
}

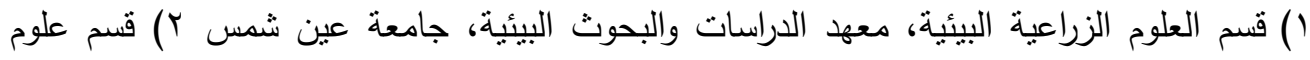

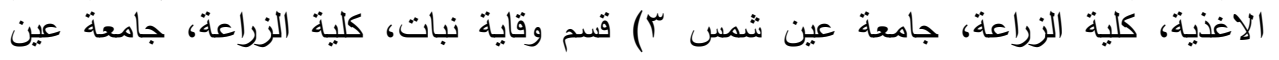

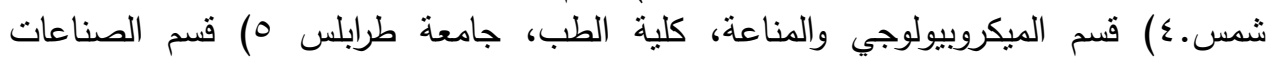
الغذائية، كلية العلوم الهندسية والتقنية، جامعة سبها

\section{ll}

استهدفت هذه الدراسة تقدير العناصر التقيلة في بعض الاغذية التقليدية في كلا من ليبيا ومصرجمع ثلاثون عينة من الطعام التقليدي الجاهز (الفول البلدي، الفلافل، الكثري) بطريقة فئة الفية عشوائية

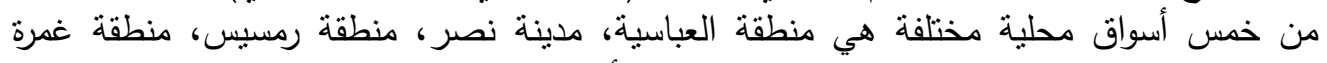

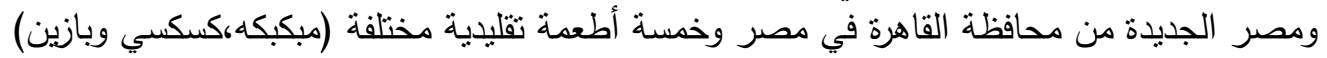

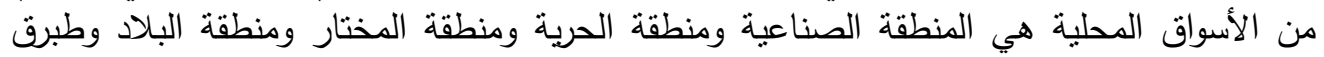

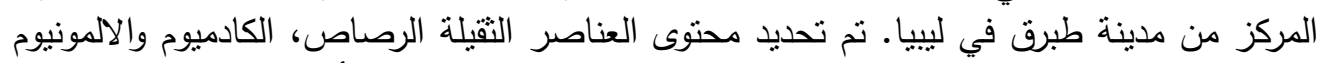

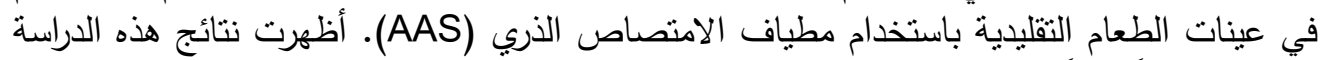

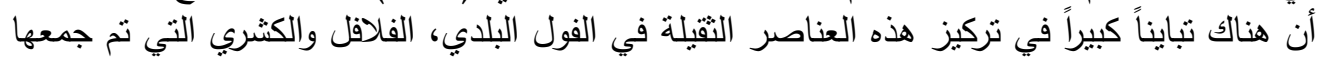

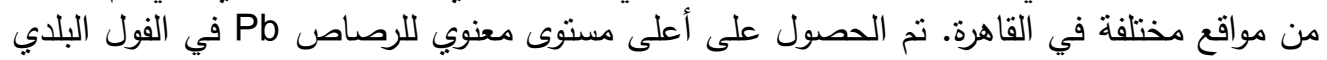

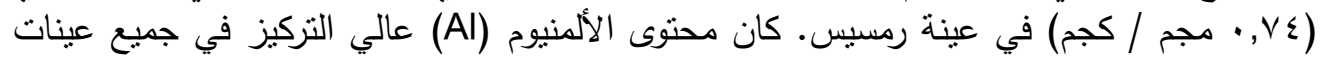

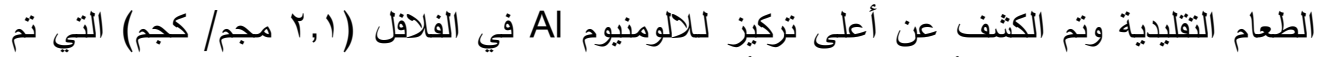

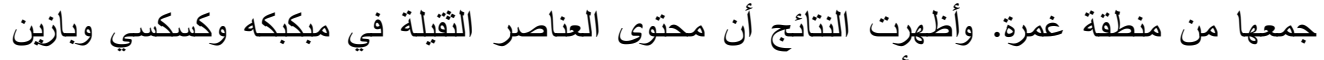

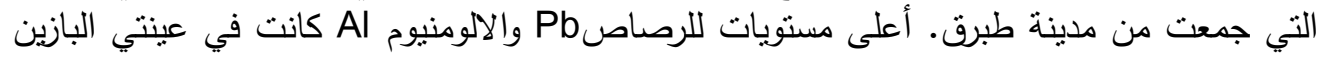

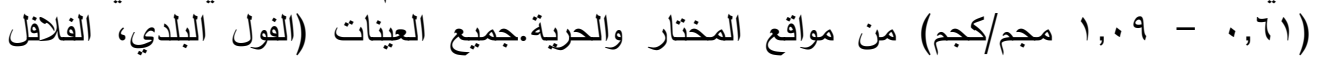

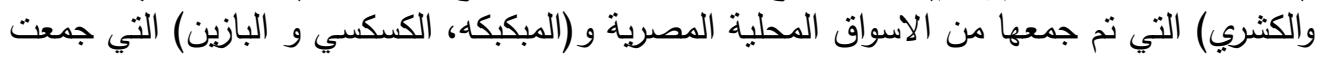

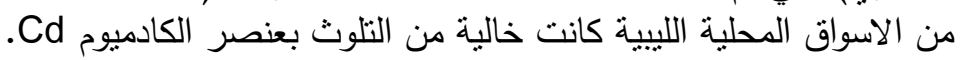
كلمات البحث: العناصر الثقيلة، التلوت، الكسكس، الكثري، الكن، الألومنيوم. 